\title{
Cellular and molecular responses of haemocytes from Ostrea edulis during in vitro infection by the parasite Bonamia ostreae
}

\author{
Benjamin Morga, Tristan Renault, Nicole Faury, Bruno Chollet, Isabelle Arzul*
}

Institut Français de Recherche pour l'Exploitation de la Mer (Ifremer), Laboratoire de Génétique et Pathologie (LGP), La Tremblade, France

\author{
*: Corresponding author: Isabelle Arzul, Tel.: +33 546762610 ; fax: +33 546762611 ; \\ email address : iarzul@ifremer.fr ; isabelle.arzul@ifremer.fr
}

\begin{abstract}
:
Bonamia ostreae is a protozoan, affiliated to the order Haplosporidia and to the phylum Cercozoa. This parasite is intracellular and infects haemocytes, cells notably involved in oyster defence mechanisms. Bonamiosis due to the parasite $B$. ostreae is a disease affecting the flat oyster, Ostrea edulis. The strategies used by protozoan parasites to circumvent host defence mechanisms remain largely unknown in marine bivalve molluscs. In the present work, in vitro experiments were carried out in order to study the interactions between haemocytes from $O$. edulis and purified parasite, B. ostreae. We monitored cellular and molecular responses of oyster haemocytes by light microscopy, flow cytometry and real-time PCR 1, 2, 4 and $8 \mathrm{~h}$ p.i. Light microscopy was used to measure parasite phagocytosis by oyster haemocytes. Parasites were observed inside haemocytes $1 \mathrm{~h} p . i$. and the parasite number increased during the time course of the experiment. Moreover, some bi-nucleated and trinucleated parasites were found within haemocytes 2 and $4 \mathrm{~h}$ p.i., respectively, suggesting that the parasite can divide inside haemocytes. Host responses to $B$. ostreae were investigated at the cellular and molecular levels using flow cytometry and real-time PCR. Phagocytosis capacity of haemocytes, esterase activity and production of radical oxygen species appeared modulated during the infection with $B$. ostreae. Expression levels of expressed sequence tags selected in this study showed variations during the experiment as soon as $1 \mathrm{~h}$ p.i. An up-regulation of galectin (OeGal), cytochrome p450 (CYP450), lysozyme, omega GST (OGST), super oxide dismutase $\mathrm{Cu} / \mathrm{Zn}(\mathrm{Oe}-\mathrm{SOD} \mathrm{Cu} / \mathrm{Zn})$ and a down-regulation of the extracellular super oxide dismutase SOD (Oe$E c S O D)$ were observed in the presence of the parasite. Finally, the open reading frames of both SODs (Oe-SOD $\mathrm{Cu} / \mathrm{Zn}$ and $\mathrm{Oe}-\mathrm{EcSOD}$ ) were completely sequenced. These findings provide new insights into the cellular and molecular bases of the host-parasite interactions between the flat oyster, $O$. edulis, and the parasite, $B$. ostreae.
\end{abstract}

\section{Graphical abstract :}

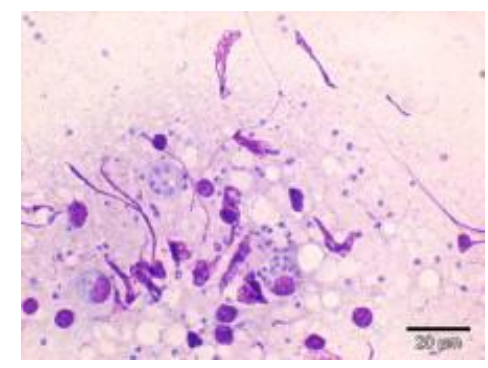

Highlights

Multiplication of parasite Bonamia ostreae occurs inside haemocytes at $2 \mathrm{~h}$ p.i. Diminution of esterases and reactive oxygen species in the host at $1 \mathrm{~h}$ p.i. Over-expression of the galectin gene (OeGal) at $1 \mathrm{~h} \mathrm{p.i.} \mathrm{Up}$ regulation of cytoplasmic super oxide dismutase (OeSOD Cu/Zn) at 2 and $4 \mathrm{~h} \mathrm{p.i.}$

Keywords : Bonamia ostreae ; Protozoan ; Ostrea edulis ; Haemocytes ; Real-time PCR ; Flow cytometry ; Super oxide dismutase 


\section{Introduction}

61 Diseases due to infectious agents (virus, bacteria or protozoan) might curb oyster production and contribute to financial losses. A better understanding of interactions between the immune system of oysters and pathogens is necessary to control the development of these diseases. However, these interactions are poorly documented in oysters in contrast with other invertebrate species such as insects and nematodes (Gravato-Nobre and Hodgkin, 2005 ; D'Argenio et al., 2001). The immune defence of invertebrates, including oysters, is based on innate immune responses. In Europe, since 1979 the flat oyster production has experienced high mortality outbreaks associated with protozoans including Bonamia ostreae (Pichot et al., 1979). This protozoan is an intracellular parasite and belongs to the order of Haplosporidae and the phylum of cercozoan (Cochennec et al., 2000 ; Carnegie et al., 2000 ; Cavalier-Smith and Chao 2003). B. ostreae infects the haemocytes, cells notably involved in oyster defence mechanisms (Cheng, 1981). Three different types of haemocytes have been described in the flat oyster, Ostrea edulis: granulocytes, large hyalinocytes and small hyalinocytes (Auffret, 1985 ; Bachère et al., 1991 ; Chagot et al., 1992 ; Mourton et al., 1992 ; Xue et al., 2001). These cells are responsible for wound repair, phagocytosis and encapsulation (Cheng, 1981 ; Fisher, 1986). The haemocytes are carried by the haemolymph in a semi-open system. Some soluble immune components such as lectins, lysosomal enzymes, and antimicrobial peptides have already been identified in the haemolymph of different bivalves species

78 (Olafsen et al., 1992; Bachère et al., 2004 ; Xue et al., 2004). The flat oyster $O$. edulis and its parasite B. ostreae represent a suitable model to study hostpathogen interactions in molluscs because of the possibility to reproduce the associated disease in experimental conditions (Mourton et al., 1992). 
Intracellular parasites have developed sophisticated strategies to escape host defence mechanisms, thereby finding unique niches where they can survive, and from which they can establish successful infection. As previously described, the internalisation of Bonamia ostreae by flat oyster haemocytes induces a diminution of esterase activities and reactive oxygen species (ROS) production after 2 hours of in vitro infection (Morga et al., 2009). Esterases are enzymes belonging to the group of hydrolases catalysing the hydrolysis of ester bonds. The respiratory burst is a series of biochemical reactions that produce highly microbicidal ROS including superoxide $\left(\mathrm{O}^{2-}\right)$, hydrogen peroxide $\left(\mathrm{H}_{2} \mathrm{O}_{2}\right)$, and hydroxyl radical $\left(\mathrm{OH}^{+}\right)$. Although radicals produced during the respiratory burst are known to be involved in the destruction of parasites in different host species including molluscs (Toreilles et al., 1996 ; Hahn and Bayne 2001 ; Humphries and Yoshino 2008), some intracellular parasites like Leishmania sp, Toxoplasma gondii and Perkinsus marinus develop strategies to evade this process which allows them to invade and multiply within host cells (Dermine and Desjardins 1999 ; Schott et al., 2003 ; Shrestha et al., 2006). Similar strategies seem to be developed by the parasite $B$. ostreae. Recently, new data obtained on flat oyster genome have allowed identifying some ESTs potentially involved in the host-parasite interactions, including the genes selected in the present study (Morga et al., 2010a).

Previous in vitro studies have examined the specificity of the host responses to infection with the parasite at the cellular or at the molecular level after 2 hours, but never by considering both simultaneously and throughout time (Morga et al., 2009, Morga et al., 2010a). The specificity of the haemocyte response has been tested using dead and live parasite.

In the present study, we have studied the kinetics of the response of haemocytes of $O$ edulis to an in vitro infection with the parasite $B$. ostreae. For that purpose, we combined flow cytometry to measure some haemocyte activities and real-time PCR analysis to measure expression levels of some genes of interest including galectin (OeGal), super oxide dismutase (Oe-SOD $\mathrm{Cu} / \mathrm{Zn}$ ), extracellular super oxide dismutase (Oe-EcSOD), cytochrome p450 (CYP450), heat shock protein 
90 (HSP90), omega gluthationne S transferase (OGST) and lysozyme. In addition, the complete open reading frames of two Ostrea edulis genes related to detoxification (Oe-SOD and Ec Oe-SOD) were determined and characterized.

110 This integrated study of the kinetics of the immune response of the Ostrea edulis to Bonamia

111 ostreae may contribute to better understand the strategies developed by the parasite to escape host 112 responses and by the oyster to eliminate the parasite and finally survive.

\section{Material and methods}

\subsection{Biological material}

Two years old flat oysters Ostrea edulis were collected from the Bay of Quiberon (Southern Brittany, France), an endemic zone regarding bonamiosis.

Haemolymph was withdrawn from the adductor muscle using a $1 \mathrm{~mL}$ syringe equipped with a needle $(0.40 \times 90 \mathrm{~mm})$ and then filtered on a $75 \mu \mathrm{m}$ mesh to eliminate debris. $10-15$ samples of haemolymph were pooled together and maintained on ice to prevent aggregation (Auffret and Oubella. 1997). Haemocyte counts were performed using a Malassez cell.

\subsubsection{Parasite}

B. ostreae was purified according to the protocol of Mialhe et al., (1988). Briefly, heavily infected oysters were selected by examination of heart tissue imprints using light microscopy. After 
132 homogenization of all the organs except the adductor muscle, the parasites were concentrated by 133 differential centrifugation on sucrose gradients and then purified by isopycnic centrifugation on a 134 Percoll gradient. Finally, the purified parasites were suspended in filtered sea water (FSW). 135 Bonamia ostreae cells were then counted using a Malassez-cell. Suspensions of purified parasites 136 were stored at $4^{\circ} \mathrm{C}$ and used within the 24 hours following the purification for in vitro infection 137 experiment.

\subsection{In vitro infection protocol}

141 Haemocytes $\left(5.10^{5}\right.$ cells $\left.\mathrm{mL}^{-1}\right)$ were incubated with live parasites at the ratio 5:1 (parasites per 142 haemocyte) at $15{ }^{\circ} \mathrm{C}$ and analysed after $1 \mathrm{~h}, 2 \mathrm{~h}, 4 \mathrm{~h}$ and $8 \mathrm{~h}$ of in vitro infection. The control consisted 143 of haemocytes alone suspended in FSW $\left(5.10^{5}\right.$ cells $\left.\mathrm{mL}^{-1}\right)$. The whole experiment was carried out 144 three times and included each time duplicate $(n=6)$.

\subsection{Flow cytometry analysis}

147 Protocols and methods used for the flow cytometry analyses have previously been described in 148 Morga et al., 2009. For each sample, 5000 events were counted using an EPICS XL 4 (Beckman 149 Coulter). Based on size discrimination, parasites or other small particles were not counted, only 150 haemocytes were taken into account for cell activity measures. Results were depicted as cell 151 cytograms and reported in log scale fluorescence levels for each marker used. Fluorescence 152 depended on the monitored parameters: non specific esterase activities, ROS production and 153 phagocytosis were measured using green fluorescence while cell mortality was measured using red 154 fluorescence. 
159 One hundred $\mu \mathrm{l}$ of cell suspensions were cytocentrifugated $\left(100 \times \mathrm{g}, 4{ }^{\circ} \mathrm{C}, 1 \mathrm{~min}\right)$, stained with 160 Hemacolor ${ }^{\circledR}$ (Merck) and examined using light microscopy. Before the infection experiment, pools 161 of haemolymph were examined in order to check the absence of the parasite. Then, for each time of 162 contact, 150 haemocytes were observed, and number of infected haemocytes, number of parasites 163 per infected hameocytes and the total number of di and trinucleated parasites were reported.

\subsection{Gene selection}

Seven ESTs were selected from $O$. edulis cDNA databases because of their potential involvement in response to infection with Bonamia ostreae. Among these genes, one encodes a cell recognition protein, the galectin (OeGal) and four are involved in post-phagocytosis degradation and cellular protection mechanisms: super oxide dismutase (Oe-SOD $\mathrm{Cu} / \mathrm{Zn}$ ), extracellular super oxide dismutase (Oe-EcSOD), cytochrome p450 (CYP450), omega gluthationne s transferase (OGST).

172 The expression of two other genes implicated in defence mechanisms (lysozyme) and stress (heat 173 shock protein 90, HSP90) was also studied.

2.6 RNA extraction and reverse transcription

177 Total RNA was extracted from haemocytes using Trizol (Trizol ${ }^{\circledR}$ reagent, Invitrogen ${ }^{\mathrm{TM}}$ ) and treated 178 with RQ1 RNAse-free DNAse (Promega) to remove remaining genomic DNA. RNA concentrations 179 were measured before and after DNase treatment. Reverse transcription (RT) was carried out as 180 previously described Morga et al., (2010) using the oligo(dT) anchor primer (5'-GAC 
CACGCGTATCGATGTCGACT(16)V-3'). Reverse transcriptase was performed using SuperScript

182 III (Invitrogen) according to the manufacturer's recommendations.

\subsection{Expression analysis of the selected ESTs by quantitative real-time PCR}

For each of the selected ESTs, forward and reverse primers were designed using primer3 software (http://biotools.umassmed.edu/bioapps/primer3 www.cgi) (Table 1). Real-time quantitative PCR reactions were duplicated and performed in a total volume of $25 \mu \mathrm{L}$ using a Mx3000 Thermocycler sequence detector (Stratagene) in 96-microwell plates. Each well $(25 \mu \mathrm{L})$ contained $5 \mu \mathrm{L}$ of cDNA dilution (1/30), $12.5 \mu \mathrm{L}$ of Brilliant ${ }^{\circledR} \mathrm{SYBR}^{\circledR}$ Green II PCR Master Mix (Stratagene), $2.5 \mu \mathrm{L}$ of each diluted primer $(3 \mu \mathrm{M})$ and $2.5 \mu \mathrm{L}$ of distilled water. Thermal cycling conditions were: 1 cycle of activation of Hot start Taq polymerase at $95^{\circ} \mathrm{C}$ for $10 \mathrm{~min} ; 40$ cycles of amplification at $95^{\circ} \mathrm{C}$ for $10 \mathrm{~s}, 60^{\circ} \mathrm{C}$ for $30 \mathrm{~s}$; and melting temperature curve analysis at $95^{\circ} \mathrm{C}$ to $60^{\circ} \mathrm{C}$ by $0.5^{\circ} \mathrm{C}$ decrease of the temperature every $10 \mathrm{~s}$. In all cases, negative controls (without cDNA) were included to rule out DNA contamination.

For each candidate gene, melting curve and gel picture were analysed in order to verify the specificity of the amplified products and that a single PCR product was amplified. PCR efficacy (E) was calculated for each primer pair by determining the slopes of standard curves. These curves were generated using a serial dilutions analysis of plasmid containing the insert of interest. Amplification efficacies were calculated according to the following equation $\mathrm{E}=10^{(1-\mathrm{slope})}$ (Pfaffl, 2001).

201 The expression of the candidate genes was normalized using the elongation factor 1 alpha 202 (GenBank, accession $\mathrm{n}^{\circ}$ EU651798) as housekeeping gene. The elongation factor alpha has 203 previously been identified as the most stable housekeeping gene for similar study (Morga et al. 204 2010b). Haemocytes alone were used as calibrator. Primers are shown in Table 1. Fold units were 205 calculated using the double delta Cts method described by Pfaffl (2001). 
$E c S O D$

210 In order to obtain the complete open reading frame (ORF) of $O e-S O D C u / Z n$ and $O e-E c S O D$, 211 RACE reactions were carried out using SMART RACE cDNA Amplification Kit from Clontech 212 according to the manufacturer's instructions. 5' and 3' primers were designed using primer 3 213 software (http://biotools.umassmed.edu/bioapps/primer3 www.cgi) (3'Oe-SOD $\mathrm{Cu} / \mathrm{Zn}$

214 TGATTAACCTGGCTGGTCCACAGTC, 215 GACTGTGGACCAGCCAGGTTAATCA

216 GTGCACATGGAGGTCATGTTGACTG, 217 TGACAGGATGGTCCTCTTCCTCCTC) and synthesized by Eurogentec. Race PCR products 218

\subsubsection{Sequencing and sequence analysis}

5'Oe-SOD

and

3'Oe-ECSOD

5'Oe-ECSOD were cloned using TOPO Vector System (Invitrogen). Several clones were selected and amplified with TOPO R and F primers in order to control the size of the insert in the plasmid.

Selected clones were first amplified using TempliPhi ${ }^{\mathrm{TM}}$ DNA Sequencing Template Amplification Kit (Amersham's). PCR products isolated from individual clones were sequenced in both ends with TOPO R and F primers (Table 1) with the sequencing kit ABI BigDye ${ }^{\circledR}$ terminator version 3.1 using an ABI PRISM ${ }^{\circledR} 3130$ XL-Avant Genetic Analyzer, a $36 \mathrm{~cm}$ capillary array and POP 7 polymer. Chromatograms were analyzed with Chromas 231 software. Sequences were then analyzed with BlastX algorithm available from the National Center for Biotechnology Information (NCBI) and the EST sequences were then submitted to dbEST and GenBank databases 
230 (http://www.ncbi.nlm.nih.gov/blast/). Complete sequences (Oe-SOD and Oe-EcSOD) were 231 deposited in GenBank and assigned under the accession numbers GU320695 and GU320696.

236 The sequence of the complete ORF of $\mathrm{Oe}-\mathrm{SOD} \mathrm{Cu} / \mathrm{Zn}$ was aligned with homologous genes from 237 GenBank database (Homo sapiens sapiens NP000445.1, Rattus norvegicus CAA79925.1, Bos 238 taurus NM174615, Salmo salar NP00111780.1, Pagrus major AA015363.1, Mytilus edulis 239 CAE46443.1, Crassostrea ariakensis ABF14366.1 and Crassostrea gigas CAD427221).

240 The sequence of the complete ORF of $O e-E c S O D$ was aligned with homologous genes from 241 GenBank database (Homo sapiens sapiens NP0003093.2, Rattus norvegicus CAA64149.1, Bos 242 taurus NP001076079.1, Salmo salar NP001134324.1, Perna canaliculus AF273766.1, Crassostrea 243 virginica BAF30874.1 Crassostrea gigas AAY60161.1 Saccostrea glomerata ACQ73551.1 and 244 Barbula unguiculata BAC53790.1 (outgroup)).

245 Sequences were aligned using ClustalW (Thompson et al., 1997) from MEGA 4 (Tamura et al., 246 2007). Phylogenic trees based on deduced amino acid sequences were constructed using the 247 Neighbour-Joining (NJ) (Saitou et al., 1987) and the Maximum parsimony (MP) method (Eck and 248 Dayhoff 1966) with the MEGA 4 software program. Statistical confidence on the inferred 249 phylogenic relationships was assessed by bootstrap of 1000 replicates. 
258 A Mann-Whitney test was performed to test the difference between the mean numbers of parasites 259 in infected haemocyte during the kinetic experiment. Flow cytometry results were expressed as 260 percentages of positive cells. In order to detect an effect of tested conditions, a two factors ANOVA 261 was performed using XLSTAT-Pro ${ }^{\circledR}$ version 7.5.3 software. Values were converted into $\mathrm{r}$ angular $262 \operatorname{arcsinus} \sqrt{ }(\%$ of positive cells $)$ before analysis to ensure the respect of a priori assumptions of 263 normality and homogeneity. In the case of rejection of $H_{0}$, an a posteriori Tukey test was used to 264 compare differences between means. Quantitative PCR results were also analysed by a two factor 265 ANOVAs using XLSTAT-Pro ${ }^{\circledR}$ version 7.5.3 software. In the case of rejection of $H_{0}$, an $a$ 266 posteriori Tukey test was used to compare differences between means.

\section{Results}

\subsection{Detection of parasites in haemocytes}

273 Bonamia ostreae appeared engulfed by haemocytes whatever the tested contact period was. 274 Percentages of infected haemocytes are $18 \%$ to $27 \%$ and mean number of parasites per infected haemocyte from 1.3 to 2.4 between $1 \mathrm{~h}$ and $8 \mathrm{~h}$ of contact (Fig. 1). The number of parasites observed inside the haemocyte was significantly more important at $4 \mathrm{~h}$ and $8 \mathrm{~h}$ compared to $1 \mathrm{~h}(\mathrm{p}<0,036$ and $\mathrm{p}<0,016$, respectively). Number of binucleated parasites inside the haemocytes increased after one 
278 hour of contact (Fig. 1). Moreover, two intrahaemocytic trinucleated parasites could be observed 279 after $4 h$.

\subsubsection{Haemocyte mortality}

284 Prior to haemocyte activity measurement, cell survival was checked by deducing cell mortality based on propidium iodide labelling. Whatever the tested condition was, percentage of live cells was never below $89,1 \%$. Cell mortality was considered equivalent between all the tested conditions.

\subsubsection{Esterases, ROS and phagocytosis activity}

In presence of parasites, the percentages of positive haemocytes showing esterase activities were significantly lower compared to the control after $1 \mathrm{~h}(\mathrm{p}<0.033), 2 \mathrm{~h}$ and $4 \mathrm{~h}(\mathrm{p}<0.004)$ of in vitro infection (Fig. 2a). Percentages of ROS positive haemocytes were significantly lower in presence of parasites than in controls at $1 \mathrm{~h}, 2 \mathrm{~h}$ and $8 \mathrm{~h}(\mathrm{p}<0.013)($ Fig. $2 \mathrm{~b})$. Lastly, a significant decrease of the percentage of haemocytes which have engulfed three beads or more was observed in haemocytes in contact with Bonamia ostreae after $2 \mathrm{~h}$ of contact $(\mathrm{p}<0.02)$ (Fig. $2 \mathrm{c})$.

\subsection{Identification and characterization of immune-related genes}

301 RACE-PCR reactions allowed obtaining the full cDNA sequence of Ostrea edulis Super Oxide 
untranslated region (1-48 nt) followed by an ORF of 471 nucleotides (49-519 nt) and finished by a

304 3'-untranslated region (520-898 nt) showing a polyadenylation signal (AATAAA) starting 79 bp upstream from the polyA tail (Fig 3). The deduced amino acid sequence presented a molecular mass of $15863.70 \mathrm{Da}$ and a predicted isoelectric point of 5.93 (http://www.expasy.ch/tools/pi_tool.html). SignalP analysis further confirmed that Oe-SOD $\mathrm{Cu} / \mathrm{Zn}$ was a cytoplasmic protein. The deduced amino acid sequence was devoid of signal peptide.

309 Multiple alignments of intracellular SOD identified in different invertebrate and vertebrate species revealed the presence of several conserved motifs and SOD signature sequences in Oe-SOD Cu/Zn.

311 Two cysteine residues $\left(\mathrm{C}^{60}\right.$ and $\left.\mathrm{C}^{149}\right)$, involved in the formation of internal disulfide bond were fully 312 conserved in Oe-SOD $\mathrm{Cu} / \mathrm{Zn}$. Four histidine residues $\left(\mathrm{H}^{50}, \mathrm{H}^{52}, \mathrm{H}^{66}\right.$, and $\left.\mathrm{H}^{123}\right)$ predicated to be 313 critical for copper $(\mathrm{Cu})$ binding, and highly consistent with other invertebrate or vertebrate SODs, 314 are present in Oe-SOD Cu/Zn (Fig. 3). Moreover, four residues involved in Zinc (Zn) binding, 315 notably three histidine $\left(\mathrm{H}^{66}, \mathrm{H}^{74}, \mathrm{H}^{83}\right)$ and one aspartate $\left(\mathrm{D}^{86}\right)$, were also identified in Oe-SOD $316 \mathrm{Cu} / \mathrm{Zn}$. Finally, Oe-SOD $\mathrm{Cu} / \mathrm{Zn}$ amino acid sequence shows two $\mathrm{Cu} / \mathrm{Zn}-\mathrm{SOD}$ family signatures : GFHVHQFGDNT and GNAGGRLACGVI.

3.3.2 Ostrea edulis Extacellular Super Oxide Dismutase Oe-EcSOD

RACE-PCR reactions allowed obtaining the full cDNA of Ostrea edulis Extracellular Super Oxide Dismutase (Oe-EcSOD). Oe-EcSOD showed a 985 nucleotide sequence containing a short 5'untranslated region (1-42 nt) followed by an ORF of $794 \mathrm{nt}(43-837 \mathrm{nt})$ and finished by a 3'untranslated region (838-985 nt) (Fig 4). The deducted amino acid sequence of the ORF region 325 showed a predicted molecular mass of $29478.38 \mathrm{Da}$ and an isoelectric point of 4.93 (http://www.expasy.ch/tools/pi_tool.html). Analysis of the deduced amino acid sequence using the 
328 peptide of 20 amino acids (MQSLIILVLAALFYVA), suggesting that $O e-E c S O D$ can be secreted. 329 The mature peptide contained a putative N-glycosylation site (NLS $\left.{ }^{41}\right)$ 330 (www.cbs.dtu.dk/services/NetNGlyc/), suggesting that $O e-E c S O D$ is a glycoprotein (Fig. 4).

\subsubsection{Phylogenetic analysis of both Ostrea edulis SOD}

334 The phylogenic trees based on amino acid sequences of $O e-S O D$ and $O e-E c S O D$ from different 335 species have been generated using Neighbour-Joining (NJ) and the Maximum Parsimony (MP) 336 methods.

337 Both phylogenic trees (NJ) (Fig.5) and (MP) (data not shown) show two distinct groups including 338 the cytoplasmic SOD sequences and the extracellular SOD sequences. Extracellular SOD group and 339 cytoplasmic SOD present two sub group, the mammal group and the invertebrate group in both 340 trees (Fig. 5). In the extracellular SOD group, "mollusc species" formed a unique branch including 341 Perna canaliculus, Crassostrea virginica, Ostrea edulis, Crassostrea gigas and Saccostrea 342 glomerata (Fig. 5). In the cytoplasmic SOD group, "mollusc species" formed a unique branch 343 including (Mytilus edulis, Crassostrea ariakensis, Ostrea edulis and Crassostrea gigas).

3.4 Expression patterns of selected genes

347 At $1 \mathrm{~h}$ of in vitro infection, Oe-Gal was significantly $(\mathrm{p}<0.01)$ over expressed (3.9) and its 348 expression slowly decreased afterwards. A significant over expression of OGST $(\mathrm{p}<0.02)$ was 349 observed at $1 \mathrm{~h}(2.1)$ while it appears stable after that time. The lysosyme gene was significantly $350(\mathrm{p}<0.01)$ over expressed at $1 \mathrm{~h}, 2 \mathrm{~h}$ and $4 \mathrm{~h}$ with a maximum expression at $2 \mathrm{~h}(4.1)$. The CYP450 351 expression was significantly $(\mathrm{p}<0.01)$ up regulated at $1 \mathrm{~h}(2.3)$ and $8 \mathrm{~h}(2.5)$. Oe-SOD was 352 significantly $(\mathrm{p}<0.006$ and 0.001$)$ over expressed at $2 \mathrm{~h}(1.9)$ and $4 \mathrm{~h}$ (1.4). Oe-EcSOD was down 
regulated at $1 \mathrm{~h}$ and not significantly regulated at $2 \mathrm{~h}, 4 \mathrm{~h}$ and $8 \mathrm{~h}$. Finally, HSP 90 was not significantly regulated during the course of the experiment (Fig. 6).

\section{Discussion}

The present work aimed at better understanding the interactions between flat oyster $O$. edulis haemocytes and the parasite Bonamia ostreae. Cellular and molecular responses were measured by light microscopy, flow cytometry and real time PCR assays at different times post incubation between hameocytes and parasites: $1 \mathrm{~h}, 2 \mathrm{~h}, 4 \mathrm{~h}$ and $8 \mathrm{~h}$.

In vitro infection was performed at the ratio of five parasites per haemocyte at $15^{\circ} \mathrm{C}$. The internalization of the parasite by the haemocytes was monitored by examination of cytocentrifugated cells.

Parasites were observed inside haemocytes as soon as $1 \mathrm{~h}$ of infection. Previous studies demonstrated that $B$. ostreae was internalized after 30 min of contact with haemocytes and was not degraded after phagocytosis (Chagot et al., 1992 ; Mourton et al., 1992). Percentages of infected haemocytes increased during the course of the experiment. Due to the difficulty to identify with certainty haemocyte types for some cytocentrifugated cells, we did not compare percentages of infected haemocytes considering cell types. However, all types of haemocytes (granulocytes, small and large hyalinocytes) were found infected as it was previously observed in several studies (Chagot, 1989 ; Cochennec et al., 2003). The mean number of parasites observed inside the infected haemocytes was significantly higher after $4 \mathrm{~h}$ and $8 \mathrm{~h}$ compared to $1 \mathrm{~h}$. This result suggests that the parasite multiplies inside the haemocytes, or that the parasites accumulate within a particular cell during the time course of the experiment. Binucleated and trinucleated parasites were observed inside hameocytes suggesting that the multiplication of the parasite rapidly occurs after the internalization. 
379 Haemocyte activities were monitored by flow cytometry according to protocols previously 380 described (Morga et al., 2009). Haemocyte mortality never exceeded 89.1\% during the experiment. 381 The internalization of the parasite did not induce haemocyte death even after $8 \mathrm{~h}$ of contact. Previous 382 in vitro studies have examined the specificity of the host responses to infection with the parasite at 383 the cellular level after 2 hours of contact, the specificity of the haemocyte response has been tested 384 using live and dead parasite (Morga et al., 2009).

385 Non specific esterase activities were recognized as reflecting the global activity of haemocytes. 386 Esterases may also be involved in the degradation of internalised particles after phagocytosis. In the 387 present study, parasites induced a decrease of the percentage of esterase positive cells after one hour 388 and more significantly after two and four hours of contact. These results, in addition to the lack of 389 haemocyte mortality, suggest a direct impact of parasites on host cell esterase activities. Catalytic enzymes present in B. ostreae (Hervio et al., 1991) might be able to inhibit hydrolases (ie esterases) 391 produced by haemocytes.

392 Similarly, the percentage of ROS positive haemocytes was lower after $1 \mathrm{~h}, 2 \mathrm{~h}$ and $8 \mathrm{~h}$ of incubation 393 with parasites compared to the control. As no cell mortality was detected, parasites may have a 394 direct impact on haemocyte ROS production. The inhibition of oxygen radical production has 395 already been described and should facilitate intracellular survival of protozoan parasites including 396 Trypanosoma sp (Penketh et al., 1987), Toxoplasma sp (Murray et al., 1980, Shrestha et al., 2006), 397 Leishmania sp (Murray, 1981), B. ostreae (Morga et al., 2009) and P. marinus (Volety and Chu, 398 1997).

399 P. marinus and rickettsia-like organisms possess acid phosphatase, partly responsible for the 400 suppression or inhibition of ROS production (Le Gall et al., 1991 ; Volety and Chu 1997). Hervio et 401 al., (1991) demonstrated the presence of acid phosphatase activity in haplosporosomes of Bonamia 402 ostreae. Acid phosphatase can inactivate the production of $\mathrm{NAD}(\mathrm{P}) \mathrm{H}$ oxidase and thus prevents 
ROS production. The level of acid phosphatase activity in B. ostreae is equivalent (Hervio et al., 1991) to levels found in several Leishmania species (Lovelace and Gottlieb, 1987) in which the inhibitor role of the NAD(P)H oxidase has been shown.

Bead phagocytosis capacity of haemocytes was significantly lower after 2 hours in presence of Bonamia ostreae compared to haemocytes alone. Cytocentrifugation observation revealed an increase of the parasite number inside infected haemocytes between 1 and 2 hours post infection. The decrease of bead phagocytosis capacity by infected haemocytes observed after 2 hours of contact with parasites could be due to the presence of parasites inside haemocytes. Goedken et al., (2005) have shown that the internalisation of the parasite $P$. marinus by haemocytes from the oyster Crassostrea virginica did not induce a difference of bead internalisation by haemocytes. The decrease of bead phagocytosis capacity and the increase of infected haemocytes during the course of the experiment support the hypothesis that the parasite $B$. ostreae mediates its own phagocytosis.

In addition to this cellular analysis of haemocytes response to an infection with the parasite $B$. ostreae, some genes have been selected for their potential interest to better understand host parasite interactions. Previous in vitro studies have examined the specificity of the host responses to infection with the parasite at the molecular level after 2 hours of contact, the specificity of the haemocyte response has been tested using live and dead parasite (Morga et al., 2010a).

Galectins are able to bind glycans present at the surface of micro organisms and favour their entrance of the pathogens inside host cells (Tasumi and Vasta, 2007). In the present study the expression level of Oe-Gal was highly up regulated at $1 \mathrm{~h}$ and slightly up regulated at $2 \mathrm{~h}$. This result suggests the participation of oyster galectin to the parasite internalization process facilitating its binding to the host cell surface. 
The expression level of the lysozyme gene appeared up regulated in haemocytes after 1, 2 and $4 \mathrm{~h}$ of contact with the parasite. Similar results were observed in Mercenaria mercenaria infected with the parasite QPX (Quahog parasite X) (Perrigault et al., 2009). Lysozyme is a lysosomal enzyme with an important defence role as it can hydrolyse bacterial components. O. edulis lysozyme was

431 previously identified by Matsumoto et al., (2006). Lysozyme activity has been detected in the body 432 fluids and tissues of many bivalve molluses and is believed to play a role in host defence and 433 digestion (Takahashi et al., 1986, Cronin et al., 2001). Lysozyme concentrations were unchanged in 434 clams Ruditapes decussatus infected by Perkinsus atlanticus (Ordás et al., 2000) and in oysters $C$. 435 virginica infected by $P$. marinus (Chu et al., 1993). However, a subsequent investigation in oysters 436 showed a slight decrease in lysozyme concentration in P. marinus infected oysters (La Peyre et al., 437 1995).

439 Four genes involved in degradation and cellular protection (OGST, CYP450, Oe-SOD Cu/Zn and 440 Oe-EcSOD), were also studied by real time PCR. CYP450 and OGST were up regulated after $1 \mathrm{~h}$ of 441 infection. This result can be related to parasite internalization and the production of toxic 442 components produced by the haemocyte and the parasite. Indeed, glutathione S-transferases play an 443 important role in the detoxification of toxic compounds of endogenous and exogenous origin 444 (Brophy and Pritchard, 1992 ; Brophy and Pritchard, 1994) and cytochrome p450 is involved in 445 various functions notably oxidative metabolism. Cytochrome p450 has been studied in other 446 bivalves subjected to parasite challenges (Tanguy et al., 2004, Perrigault et al., 2009). Perrigault et 447 al., (2009) reported an up regulation of this gene after 14 days post QPX infection with in $M$. 448 mercenaria.

449 Two genes (Oe-SOD $\mathrm{Cu} / \mathrm{Zn}$, Oe-EcSOD) involved in the oxidative stress were completely 450 characterized and their expression levels were studied. Oe-SOD $\mathrm{Cu} / \mathrm{Zn}$ homologous genes have 451 been recently characterized in other oyster species including C. gigas (Huvet et al., 2004) and 
Crassostrea virginica (Tanguy et al., 2004). Oe-EcSOD appeared similar to the permin or cavortin

453 previously identified in other bivalve species such as Perna canalialus, C. gigas and C. virginica 454 (Scotti et al., 2001 ; Scotti et al., 2007). Surprisingly, these two genes presented a different 455 expression pattern during the experiment. The cytoplasmic SOD appeared slightly up regulated 456 after $2 \mathrm{~h}$ and $4 \mathrm{~h}$ while the extracellular SOD was down regulated after $1 \mathrm{~h}$ and not significantly 457 modulated at $2 \mathrm{~h}, 4 \mathrm{~h}$ and $8 \mathrm{~h}$. The down regulation observed after $1 \mathrm{~h}$ of contact could be induced by 458 the parasite in order to facilitate its own internalization and to escape degradation before 459 internalization. The EC-SOD in Saccostrea glomerata was found up regulated in Marteilia sydneyi 460 resistant oyster (Green et al., 2009). Cytoplasmic SOD up regulation might reflect the cell response 461 to parasite internalization. ROS production showed a decrease after $1 \mathrm{~h}, 2 \mathrm{~h}$ and $4 \mathrm{~h}$. Decrease of ROS 462 production could be related to the up regulation of the cytoplasmic SOD at $2 \mathrm{~h}$ and $4 \mathrm{~h}$ of haemocyte 463 incubation with the parasite.

465 The present work is the first study combining cellular and molecular approaches to investigate the 466 interactions between haemocytes from $O$. edulis and the parasite B. ostreae. Results showed 467 internalisation of the parasite after $1 \mathrm{~h}$ of contact and an increase of the number of the parasites 468 observed inside infected haemocytes during the time course of the experiment suggesting a 469 multiplication of the parasite especially after $2 \mathrm{~h}$ of contact. Flow cytometry revealed a general 470 decrease of esterase activities, ROS production and phagocytosis capacity in infected cells. Real 471 time PCR measures showed an up regulation of some genes potentially involved in the entrance of 472 the parasite within host cells (e.g. OeGal) or involved in the detoxification and degradation like 473 lysozyme or cytochrome P450. Such results contribute to better understand how the flat oyster 474 reacts against the infection with $B$. ostreae and how the parasite may escape these defence 475 mechanisms. 


\section{Acknowledgement}

479 The authors are very grateful to anonymous reviewers for revising the manuscript. The Région of 480 Poitou Charentes supported in part this research. The authors thank Raphael Brizard for technical 481 assistance for the maintenance of oysters in Ifremer La Tremblade quarantine facilities.

482

483 


\section{References}

Auffret M., 1985. Morphologie comparative des types hémocytaires chez quelques mollusques bivalves d'intérêt commercial, Thèse De 3ème Cycle Université De Bretagne Occidentale.

491 in vitro measurement and experimental modulation by xenobiotics. Comp Biochem Physiol A 118, $492705-712$.

494 Bachère E., Hervio D., Mialhe E., 1991. Luminol dependent chemiluminescence by hemocytes of two marine bivalves, Ostrea edulis and Crassostrea gigas. Dis Aquat Org 11, 173-180.

Bachere E., Gueguen Y., Gonzalez M., de Lorgeril J., Garnier J., Romestand B., 2004. Insights into 498 the anti-microbial defense of marine invertebrates: the penaeid shrimps and the oyster Crassostrea 499 gigas. Immunol. Rev. 198, 149-168.

501 Brophy P.M. and Pritchard D.I., 1992. Metabolism of lipid peroxidation products by the gastro502 intestinal nematodes Necator americanus, Ancylostoma ceylanicum and Heligmosomoides 503 polygyrus. Int J Parasitol. 22, 1009-1012. their potential as targets for immuno and chemotherapy. Exp Parasitol. 79, 89-96. 
508 Carnegie R.B., Barber B.J., Culloty S.C., Figueras A.J., Distel D.L., 2000. Development of a PCR 509 assay for detection of the oyster pathogen Bonamia ostreae and support for its inclusion in the 510 Haplosporidia. Dis Aquat Org 42, 199-206.

512 Cavalier-Smith T. and Chao E.E., 2003. Phylogeny and classification of phylum Cercozoa 513 (Protozoa). Protist 154, 341-358.

515 Chagot D., 1989. Caractérisation morphologique et fonctionnelle des hémocytes d'Ostrea edulis et 516 de Crassostrea gigas, mollusques bivalves. Etude in vitro de leurs interactions avec le protozoaire 517 Bonamia ostreae (Acestospora). Thèse EPHE Sciences de la vie et de la terre, Université de 518 Montpellier. 151.

520 Chagot D., Boulo V., Hervio D., Mialhe E., Bachere E., C. Mourton, Grizel H., 1992. Interactions 521 between Bonamia ostreae (Protozoa: Ascetospora) and hemocytes of Ostrea edulis and Crassostrea 522 gigas (Mollusca: Bivalvia): entry mechanisms. J Invertebr Pathol 59, 241-249.

524 Cheng T.C., 1981. Invertebrate blood Cells, Academic Press of London.

526 Cochennec N., Le Roux F., Berthe F., Gerard A., 2000. Detection of Bonamia ostreae based on 527 small subunit ribosomal probe. J Invertebr Pathol 76, 26-32.

529 Chu F.-L.E., La Peyre J.F., Burreson C.S., 1993. Perkinsus marinus infection and potential defense 530 related activities in eastern oysters, Crassostrea virginica-Salinity effects. J Invertebr Pathol. 62, $531 \quad 226-232$. 
533 Cochennec-Laureau N., Auffret M., Renault T., Langlade A., 2003. Changes in circulating and 534 tissue-infiltrating hemocyte parameters of European flat oysters, Ostrea edulis, naturally infected 535 with Bonamia ostreae. J Invertebr Pathol 83, 23-30.

537 Cronin M.A., Culloty S.C., Mulcahy M.F., 2001. Lysozyme activity and protein concentration in 538 the haemolymph of the flat oyster Ostrea edulis (L.). Fish Shellfish Immunol 11, 611-622.

540 D'Argenio D.A., Gallagher L.A., Berg C.A., Manoil C., 2001. Drosophila as a model host for $541 \quad$ Pseudomonas aeruginosa infection. J. Bacteriol. 183, 1466-1471.

543 Dermine J.-F. and Desjardins M., 1999. Survival of intracellular pathogens within macrophages. 544 Protoplasma 210, 11-24.

546 Eck R.V. and Dayhoff M.O., 1966. Atlas of Protein Sequence and Structure. National Biomedical 547 Research Foundation, Silver Springs, Maryland.

549 Fisher S.W., 1986. Structure and functions of oyster hemocytes. In: M. Brehélin, Editor, Immunity 550 in invertebrates. 25-35.

552 Gravato-Nobre M.J. and Hodgkin J., 2005. Caenorhabditis elegans as a model for innate immunity 553 to pathogens. Cell. Microbiol. 7, 741-751. 
555 Green T.J., Tom J., Dixon T.J., Devic E., Adlard R.D. Barnes A.C., 2009. Differential expression of 556 genes encoding anti-oxidant enzymes in Sydney rock oysters, Saccostrea glomerata (Gould) 557 selected for disease resistance. Fish Shellfish Immunol. 26, 799-810.

559 Goedken M., Morsey B., Sunila., de Guise S., 2005. Immunomodulation of Crassostrea ggas and 560 Crassostrea virginica cellular defense mechanism by Perkinsus marinus. J. Shellfish Res 24, $487-$ 561496.

Hahn B.R. and Bayne C.J., 2001. Killing of Schistosoma mansoni sporocysts by hemocytes from resistant Biomphalaria glabrata: role of reactive oxygen species. J Parasitol 87, 292-299.

Hervio D., Chagot D., Godin P., Grizel H., Mialhe E., 1991. Localization and characterization of acid phosphatase activity in Bonamia ostreae (Ascetospora), an intrahemocytic protozoan parasite of the flat oyster Ostrea edulis (Bivalvia). Dis Aquat Org. 11, 67-70.

Humphries J.E. and Yoshino T.P., 2008. Regulation of hydrogen peroxide release in circulating hemocytes of the planorbid snail Biomphalaria glabrata. Dev Comp Immunol 32, 554-562.

Huvet A., Herpin A., Lionel D., Labreuche Y., Samain J.-F., Cunningham C., 2004. The identification of genes from the oyster Crassostrea gigas that are differentially expressed in progeny exhibiting opposed susceptibility to summer mortality. Gene 343, 211-220. Pacific oysters following challenge by the protozoan Perkinsus marinus. Fish Shellfish Immunol 5, 179-190. 
581 Le Gall G., Miahle E., Chagot D., Grizel H., 1991. Epizootiological study of rickettsiosis of the 582 Saint-Jacques scallop Pecten maximus. Dis Aquat Org 10, 139-145.

584 Lovelace J.K. and Gottlieb M., 1987. Effect of tunicamycin on the extracellular acid phosphatase of 585 Leishmania donovani promastigotes. Mol Biochem Parasitol 22, 19-28.

587 Matsumoto T., Nakamura A.M., Takahashi K.G., 2006. Cloning of cDNAq and hybridization 588 analysis of lysozymes from two oyster species, Crassostrea gigas and Ostre edulis. Comp Biochem 589 Physiol B Biochem Mol Bio 145, 325-330

591 Mialhe E., Bachere E., Chagot D., Grizel H., 1988. Isolation and purification of the protozoan 592 Bonamia ostreae (Pichot et al. 1980), a parasite affecting the flat oyster Ostrea edulis (L.). 593 Aquaculture. 71, 293-299.

595 Morga B., Arzul I., Chollet B., Renault T., 2009. Infection with the protozoan parasite Bonamia 596 ostreae modifies in vitro haemocyte activities of flat oyster Ostrea edulis. Fish Shellfish Immunol. $597 \quad 26,836-842$.

599 Morga B., Arzul I., Faury N., Segarra A., Chollet B., Renault T., 2010a. Molecular responses of 600 Ostrea edulis haemocytes to an in vitro infection with Bonamia ostreae. Dev Comp Immunol (in 601 press). 
603 Morga B., Arzul I., Faury N., Renault T., 2010b. Identification of genes from flat oyster Ostrea 604 edulis as suitable housekeeping genes for quantitative real time PCR. Fish Shellfish Immunol, 29, $605937-945$.

606

607 Mourton C., Boulo V., Chagot D., Hervio D., Bachere E., Mialhe E., Grizel H., 1992. Interactions 608 between Bonamia ostreae (Protozoa: Ascetospora) and hemocytes of Ostrea edulis and Crassostrea 609 gigas (Mollusca: Bivalvia): in vitro system establishment. J Invertebr Pathol, 59, 235-240.

610

611 Murray H.W., Nathan C.F., Cohn Z.A., 1980. Macrophage oxygen-dependent antimicrobial 612 activity. J Exp Med 152, 1610-1624.

613

614 Murray H.W., 1981. Susceptibily of leishmania to oxygen intermediate and killing by normal 615 macrophage. J Exp Med 153, 1302-1315.

616

617 Olafsen J.A., Fletcher T.C., Grant P.T., 1992. Agglutinin activity in Pacific oyster (Crassostrea 618 gigas) hemolymph following in vivo Vibrio anguillarum challenge. Dev. Comp. Immunol. 16, 123619138.

620

621 Ordás M.C., Novoa B., Faisal M., McLaughlin S., Figueras A., 2001. Proteolytic activity of 622 cultured Pseudoperkinsus tapetis extracellular products. Comp Biochem and Physiol B Bioche Mol 623 Biol. 130, 199-206.

625 Penketh P.G., Kennedy W.P.K., Patton C.L., Sartorelli A.C., 1987.Trypanosomatid hydrogen 626 peroxyde metabolism. FEBS Lett 221, 427-431. 
628 Perrigault M., Tanguy A., Allam B., 2009. Identification and expression of differentially expressed 629 genes in the hard clam, Mercenaria mercenaria, in response to quahog parasite unknown (QPX). 630 BMC Genomics 10, 377-387.

632 Pfall MW., 2001. A new mathematical model for relative quantificationin real-time RT-PCR. 633 Nucleic Acid Res. 29, 2002-2007.

635 Pichot Y., Comps M., Tige G., Grizel H., Rabouin M.A., 1979. Research on Bonamia ostreae gen. 636 n., sp. n., a new parasite of the flat oyster Ostrea edulis L. Rev Trav Inst Pêches Marit 43, 131-140.

638 Saitou N. and Nei M., 1987. The neighbor-joining method: A new method for reconstructing 639 phylogenetic trees. Molecular Biology and Evolution. 4, 406-425.

641 Schott E.J., Pecher W.T., Okafor F., Vasta G.R., 2003. The protistan parasite Perkinsus marinus is 642 resistant to selected reactive oxygen species. Exp Parasitol 105, 232-240.

644 Scotti P.D., Dearing S.C., Greenwood D.R., Newcomb R.D., 2001. Pernin: a novel, self645 aggregating haemolymph protein from the New Zealand green-lipped mussel, Perna canaliculus 646 (Bivalvia: Mytilidae). Comp Biochem Phys 128B, 767-779.

648 Scotti P.D., Dearing S.C., Greenwood D.R, 2007. Characterisation of cavortin, the major 649 haemolymph protein of the Pacific oyster (Crassostrea gigas). New Zeal J Mar Freshwater Res 41, 650 91-101. 
652 Shrestha S.P., Tomita T., Weiss L.M., Orlofsky A., 2006. Proliferation of Toxoplasma gondii in 653 inflammatory macrophages in vivo is associated with diminished oxygen radical production in the 654 host cell. Int J Parasitol 36, 433-441.

656 Takahashi K., Mori K., Nomura T., 1986. Occurrence and characterization of lysozyme in the 657 marine bivalves. Nippon Suisan Gakkai Shi, 52, 863-868.

658

659 Tamura K., Dudley J., Nei M., Kumar S., 2007. MEGA4: Molecular Evolutionary Genetics 660 Analysis (MEGA) software version 4.0. Molecular Biology and Evolution. 24, 1596-1599.

662 Tanguy A., Guo X., Ford S.E., 2004. Discovery of genes expressed in response to Perkinsus 663 marinus challenge in Eastern (Crassostrea virginica) and Pacific (Crassostrea gigas) oysters. Gene. $664338,121-131$.

665

666 Tasumi S. and Vasta GR., 2007. A galectin of unique domain organization from hemocytes of the 667 Eastern oyster (Crassostrea virginica) is a receptor for the protistan parasite Perkinsus marinus. J 668 Immunol. 179. 3086-3098.

669

670 Thompson J.D., Gibson T.J., Plewniak F., Jeanmougin F., Higgins D.G., 1997. The Clustal X 671 windows interface: flexible strategies for multiple sequence alignment aided by quality tools. 672 Nucleic Acids Res. 24, 4876-4882.

674 Toreilles J., Guerin M.C., Roch P., 1996. Reactive oxygen species and defense mechanisms in 675 marine bivalves. CR Acad Sci Paris, série III; science de la vie 319, 209-218. 
677 Volety A.K. and Chu F.-L.E., 1997. Acid phosphatase activity in Perkinsus marinus, the protistan 678 parasite of the American oyster, Crassostrea Virginica. J Parasitol 83, 1093-1098.

679

680 Xue Q.-G., Renault T., Chilmonczyk S., 2001. Flow cytometric assessment of haemocyte sub681 populations in the European flat oyster, Ostrea edulis, haemolymph. Fish Shellfish Immunol 11, $682 \quad 557-567$.

683

684 Xue Q.-G., Schey K.L., Volety A.K., Chu F.-L.E., La Peyre J.F., 2004. Purification and 685 characterization of lysozyme from plasma of the eastern oyster (Crassostrea virginica), Comp. 686 Biochem. Physiol. B. 139, 11-25.

687

688

689

690

691 


\section{Figure captions}

694 Figure 1 Mean number of parasites observed inside infected haemocytes and total number of 695 binucleated cells observed inside haemocytes. Bars represent standard deviation of the mean 696 number of parasites observed inside infected haemocytes.

Figure 2 Flow cytometry analysis for esterase's activities, ROS and phagocytosis activity.

2a Percentages of positive haemocytes for non specific esterase activities after $1 \mathrm{~h}, 2 \mathrm{~h}, 4 \mathrm{~h}$ and $8 \mathrm{~h}$ of 701 incubation with parasites at 5:1 ratio. Values are means of three replicates and bars represent standard deviation $(n=6) . *$ indicates a significant difference of positive cells compared to the control.

$2 \mathrm{~b}$ Percentages of positive haemocytes for ROS production after $1 \mathrm{~h}, 2 \mathrm{~h}, 4 \mathrm{~h}$ and $8 \mathrm{~h}$ of incubation with parasites at 5:1 ratio. Values are means of three replicates and bars represent standard deviation $(\mathrm{n}=6) . *$ indicates a significant difference of positive cells compared to the control

$2 \mathrm{c}$ Percentages of positive haemocytes for phagocytosis after $1 \mathrm{~h}, 2 \mathrm{~h}, 4 \mathrm{~h}$ and $8 \mathrm{~h}$ of incubation with parasites at 5:1 ratio. Values are means of three replicates and bars represent standard deviation $(n=6) . *$ indicates a significant difference of positive cells compared to the control

711 Figure 3 Complete ORF nucleotide and deduced amino acid sequences of the flat oyster $O e$-SOD $712 C u / Z n$. ORF contains some conserved (boxed) amino acids $\left(\mathrm{C}^{60}, \mathrm{C}^{149}, \mathrm{H}^{50}, \mathrm{H}^{52}, \mathrm{H}^{66}, \mathrm{H}^{66}, \mathrm{H}^{74}\right.$, $713 \mathrm{H}^{83}$ and $\mathrm{H}^{123}$ and $\mathrm{D}^{86}$ ) and signature (surrounded) amino acids (GFHVHQFGDNT and 714 GNAGGRLACGVI). 
717 Figure 4 Complete ORF nucleotide and deduced amino acid sequences of the flat oyster Oe718 EcSOD. ORF contains a signal peptide (MQSLIILVLAALFYVA ${ }^{20}$ ) and a glycosylation site $719\left(\mathrm{NLS}^{41}\right)$ boxed and surrounded respectively on the sequence. The polyadenylation signal 720 (AATAAA) is underlined in grey.

722 Figure 5 Neighbour-joining (NJ) tree showing phylogenetic analysis of both SOD (cytoplasmic and 723 extracellar) amino acid sequences from various species. The tree is based on 1000 bootstrap 724 replications. The scale for branch length ( 0.1 substitutions/site) is shown below the tree.

726 Figure 6 Relative expression by quantitative PCR of selected genes (HSP 90, CYP450, OGST, Oe727 SOD Cu/Zn, Oe-EcSOD, OeGal and lysozyme) after 1h, 2h, 4h and $8 \mathrm{~h}$ of incubation with Bonamia 728 ostreae. Expression levels were normalized to EF1- $\alpha$ and presented as relative expression to 729 controls (mean $\pm \mathrm{SD}, \mathrm{n}=4$ ). Controls are arbitrarily assigned a value of $1 . *$ indicates a significant 730 difference of gene expression compared to controls 


\begin{tabular}{|c|c|c|c|}
\hline Name & Oligonucleotide sequence (5'-3') & $\begin{array}{l}\text { Concentration } \\
\text { of Forward } \\
\text { primer }(\mu \mathrm{M})\end{array}$ & $\begin{array}{l}\text { Concentration } \\
\text { of Reverse } \\
\text { primer }(\mu M)\end{array}$ \\
\hline OGST & $\begin{array}{l}\text { Forward: GGTCGTCAGGGGTCAGTTT } \\
\text { Reverse: GGTTCCCGTTCTTGAGCA }\end{array}$ & 3 & 3 \\
\hline CYTOP450 & $\begin{array}{l}\text { Forward:GTCATCAAGCGAATGCGATA } \\
\text { Reverse: GGAGAGCTCCCTCATTTTCC }\end{array}$ & 3 & 3 \\
\hline Hsp90 & $\begin{array}{l}\text { Forward: TTTGTGGAACGGGTCAAAA } \\
\text { Reverse:AACGTCGAGCACAGTCGAG }\end{array}$ & 3 & 3 \\
\hline OeGal & $\begin{array}{l}\text { Forward: TCGGAGGTCGCCCTTAAT } \\
\text { Reverse: TTGCCGTGAACAATCAACA }\end{array}$ & 3 & 3 \\
\hline Lysozyme & $\begin{array}{l}\text { Forward: TTGGAAATACCCGCAGGA } \\
\text { Reverse: ATATCGGACGCCTGCTTG }\end{array}$ & 3 & 3 \\
\hline Oe-EcSOD & $\begin{array}{l}\text { Forward:GAGGAGGAAGAGGACCATCC } \\
\text { Reverse: ATTTTCCTCCGCTTTGTGTG }\end{array}$ & 2,5 & 2,5 \\
\hline Oe-SOD & $\begin{array}{l}\text { Forward: TCGTCAATGTCAGCGTGAA } \\
\text { Reverse: AAATGTTGGGGCTGGTGA }\end{array}$ & 3 & 3 \\
\hline ElongPCRQ5m & $\begin{array}{l}\text { Forward: GTCGCTCACAGAAGCTGTACC } \\
\text { Reverse: CCAGGGTGGTTCAAGATGAT }\end{array}$ & 3 & 3 \\
\hline Topo F & GACCATGATTACGCCAAGC & & \\
\hline Topo R & CCCAGTCACGACGTTG & & \\
\hline
\end{tabular}

Table 1 Combinations of primers used in quantitative PCR assays 


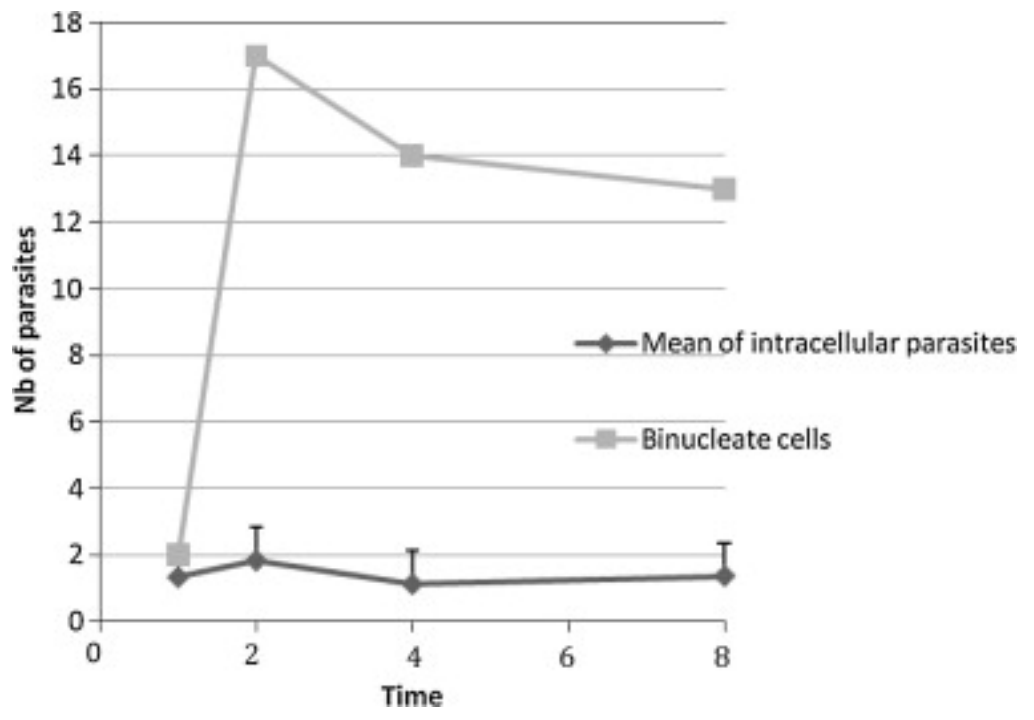

Fig1 

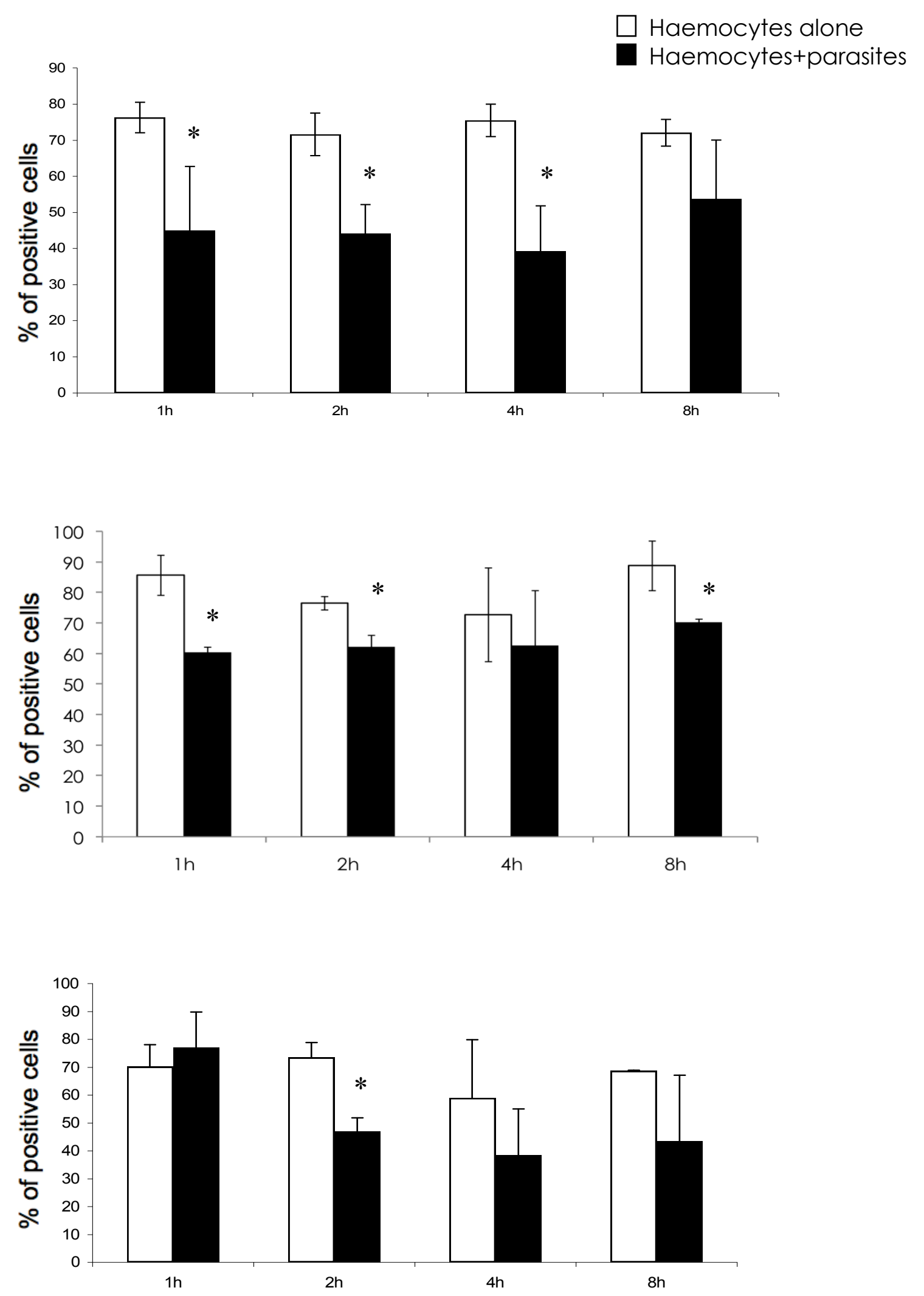


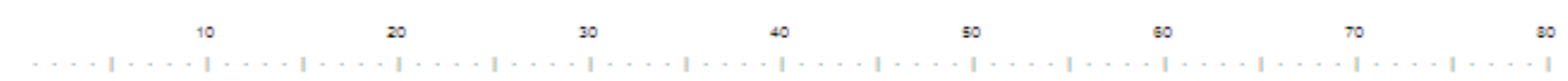
AAGAAAAA TTTGCTGTACTCGCCGGCGTGTTTAGCAAAGATTCACTATGTCCGCATTAAAGGCTGTCTGTGTACTGAA BO

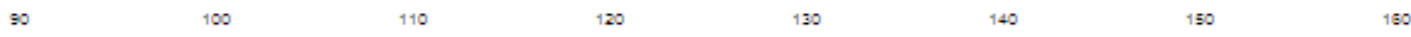
GGGTGCAGATAA CAGTGTTA CAGGAA CAGTGCA CTTTAGTCAAGAGGCA TCAGGTTCCCCCGTGACTCTTACTGGGGAGA 160

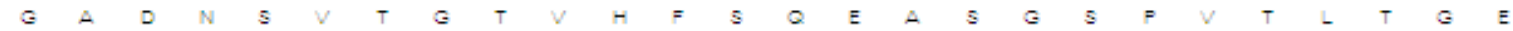

$170 \quad 130 \quad 190 \quad 200 \quad 210 \quad 230 \quad 240$ TCAGTGGGTTGGCA CCAGGACA CA TGGATTCCATGTTCATCAGTTTGGAGA CAACA CCAATGGTTGTATCAGTGCTGGA Z4O

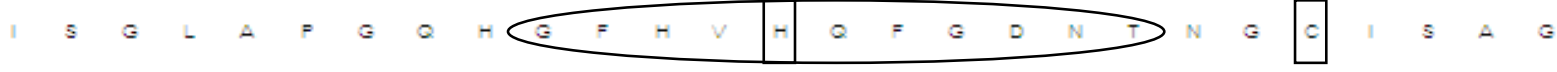

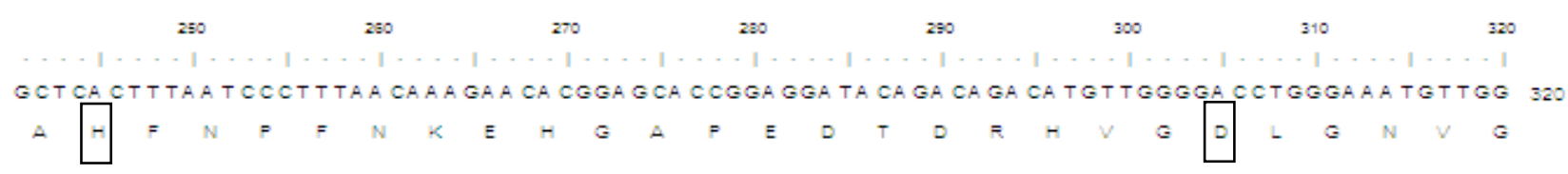
$\begin{array}{llllllll}330 & 340 & 350 & 390 & 390 & 390 & 400\end{array}$

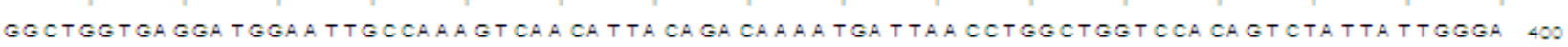

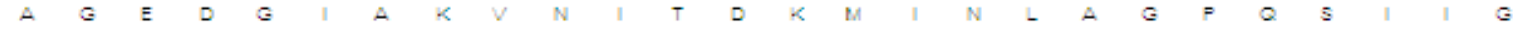
$410 \quad 420 \quad 430 \quad 440 \quad 450 \quad 450 \quad 40$ GA CTA TGGTGATTCA CGCTGA CATTGA CGATCTTGGAAAAGGAGGTCATGA CT CA GAAGA CGA CTGGTAATGCTGGT LAN

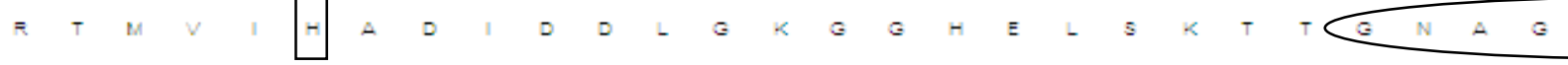

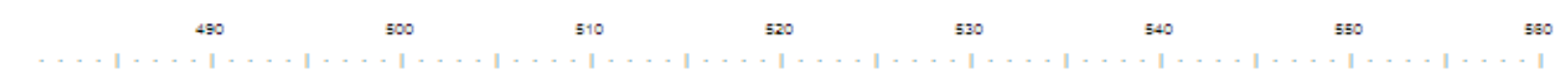

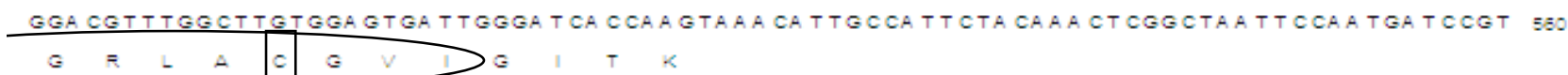

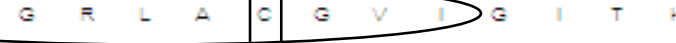

\begin{tabular}{|c|}
\hline 570 \\
\hline
\end{tabular}
A CCA CCOTGTTAGGATTTGTGTTGTTCGTCAGGTTCATAGTGATTGTTTCAAGTCTCCATGAATGTCATTAATAAAAT G40

$\begin{array}{llllllll}650 & 680 & 690 & 690 & 690 & 700 & 710 & 720\end{array}$ TAA TCA CTGTA TA CTTGAAAGT CA CATAGTTCTGTCTTCTTGTACTTTGGTATTCGGTGCAGTGAAATGATATCTTCAT 72

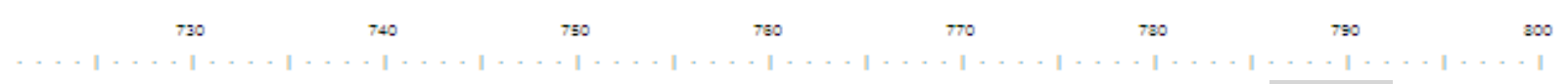
CATGTCTA CGATCTATTATTGGATGCTTCATGACATTGATTAATTAAATTTAACAATGTAGTCAATAAATCTATGTT BOO

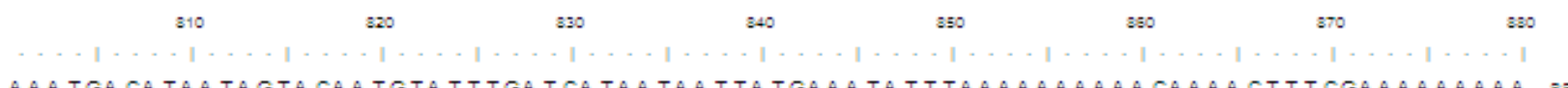

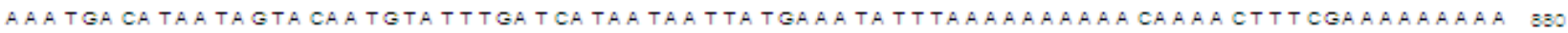

$\sec$

A A A A A A A A A A A A A A B 393

Fig 3 


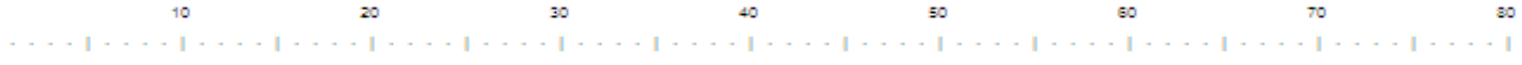
GGTTCTTTGCCTGAATTTCTGGTCAACA CCGTGGTAGGAA CGATGCAGTCTCTAATCATTTTGGTCCTGGCGGCTCTGTT BO

M Q 5 L I I L V L A A L

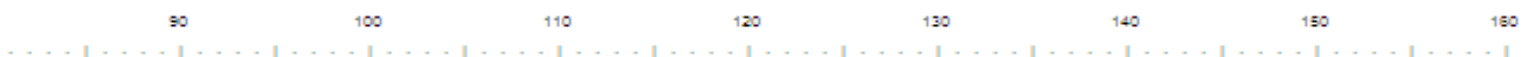
TTA CGTGGCCCOTGGA CGGGCTGTAGATTGTAGT CA GGGAGA CATTTCTCA TCTCCAAGA CGAGGTGAACTTTCTGAAAG 160

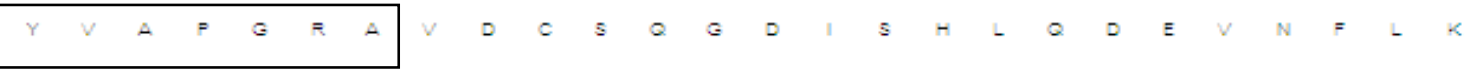

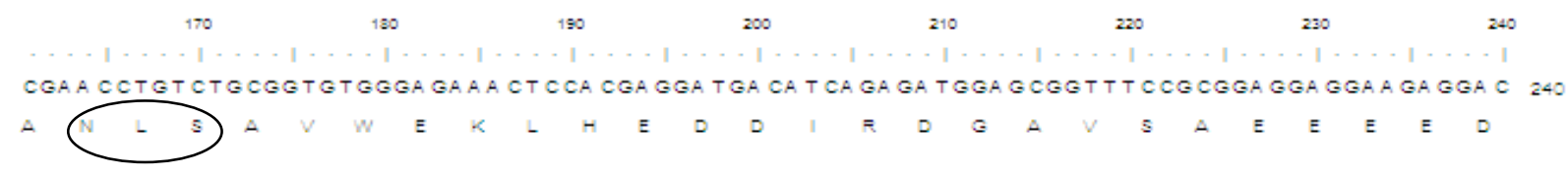

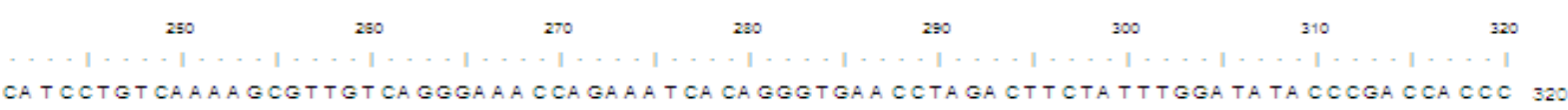

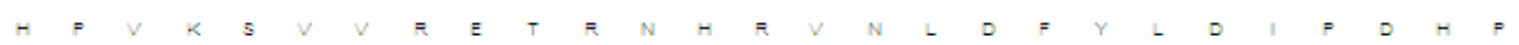
330
$\ldots 1$

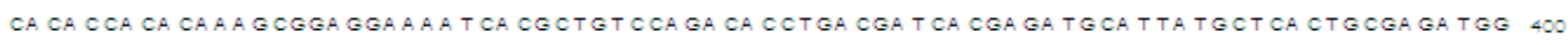

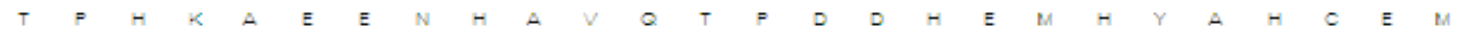

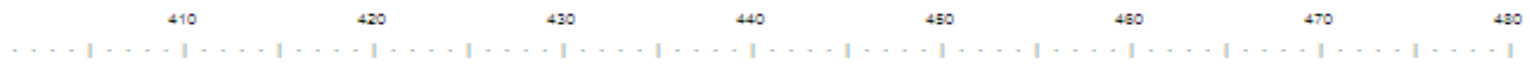
AA CCAAA CA CCA CCTGGTCAGTTATCTTCA CCA CAAAGTCCA CGGCAGCATTCA CA TGGTGCAGGAGGGACA CGGGGAC 480

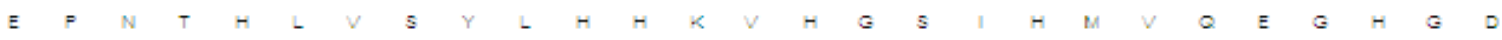

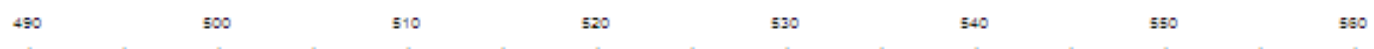
GTGCA CA TGGAGGTCATGTTGACTGGTTTCAACA CTAGTGAGGA CTT CGCCAGCCACCATCA CGQCCTTCACATGCACGA 560

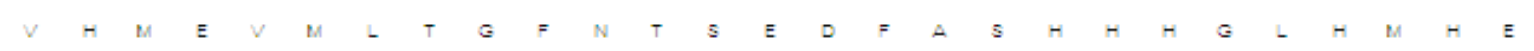
$\begin{array}{cccccc}570 & 580 & 590 & 600 & 510 & 520\end{array}$

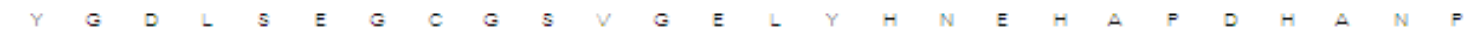

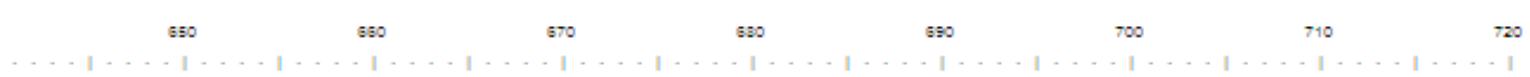

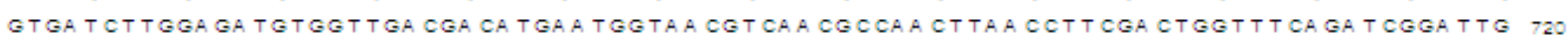

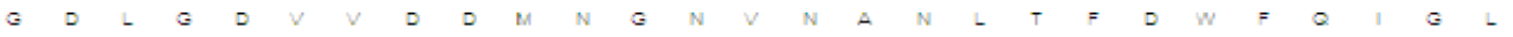
$\begin{array}{lllllll}730 & 740 & 750 & 790 & 770 & 730 & 790\end{array}$ GCTGATGGCATCCTAGgGCGCTCTCTAGTGTTTCTCCAAGGCGACCATAA CCAGGA CAAAGTGA CA GA TAGCCTGCTG BOD

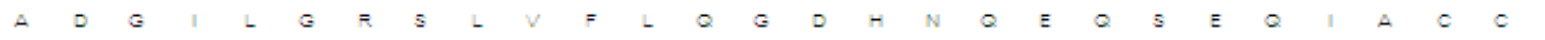

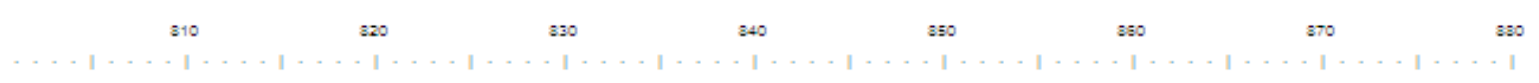
CATTATCGgCCGTGCGAGCGTATCAGACCA CCACTAGAGGTCGCCACAAAGTTCATCCATCACTGTCCTCCTGAACCGAA BSO $G=A S V B D H$

$890 \quad 900 \quad 910 \quad 920 \quad 930 \quad 940 \quad 9509$
AGTAGCCATCCTAGTTAAAAGAGTGCATTTGTTCTGTTGTATTTCTTCATTAAAGTAGAGGAGATAA CCTACCTAAAAA IGO

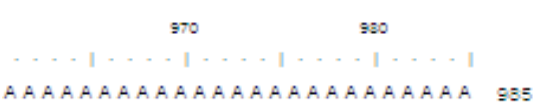

Fig 4 


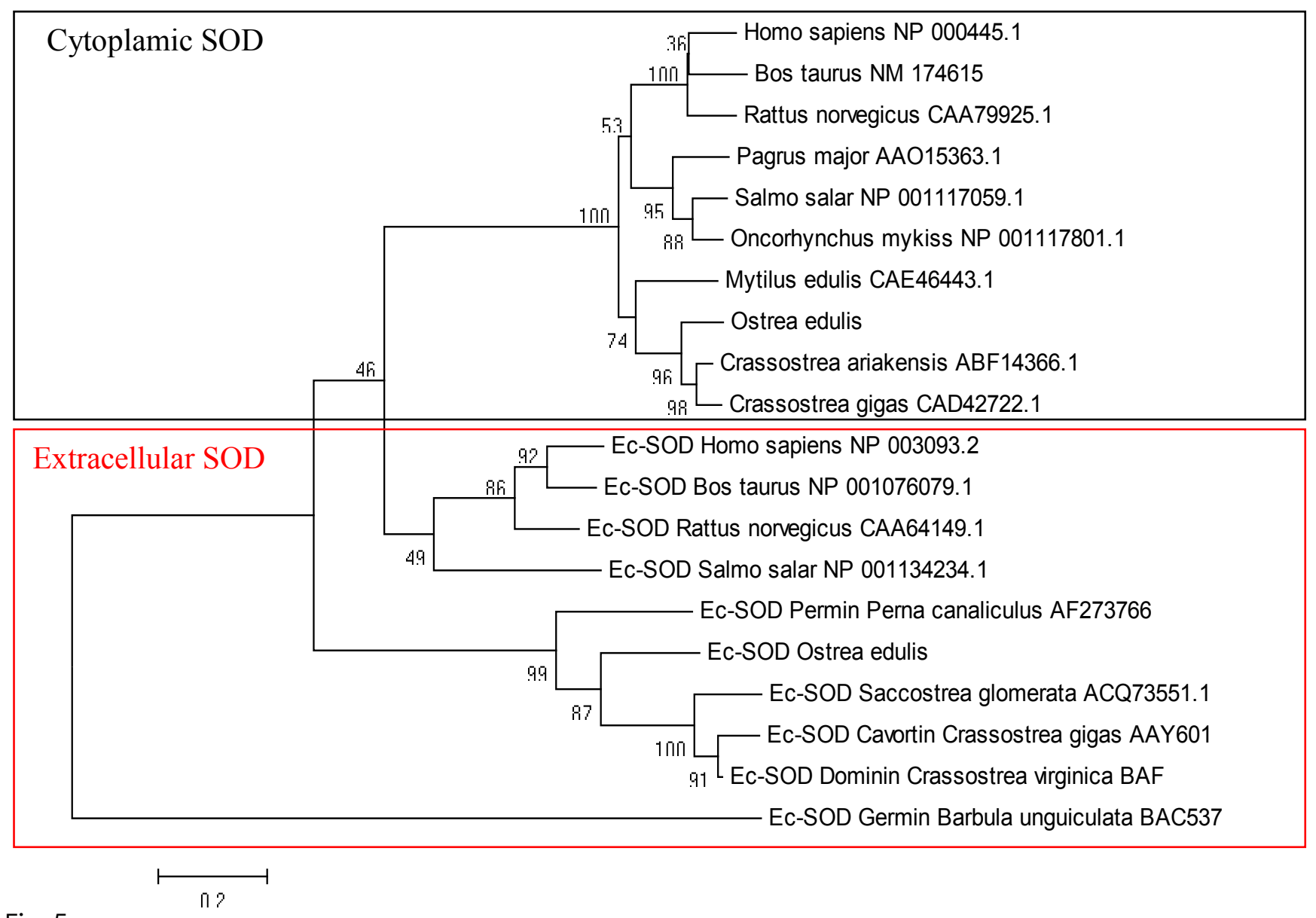

Fig 5 
$2^{-\Delta \Delta C t}$

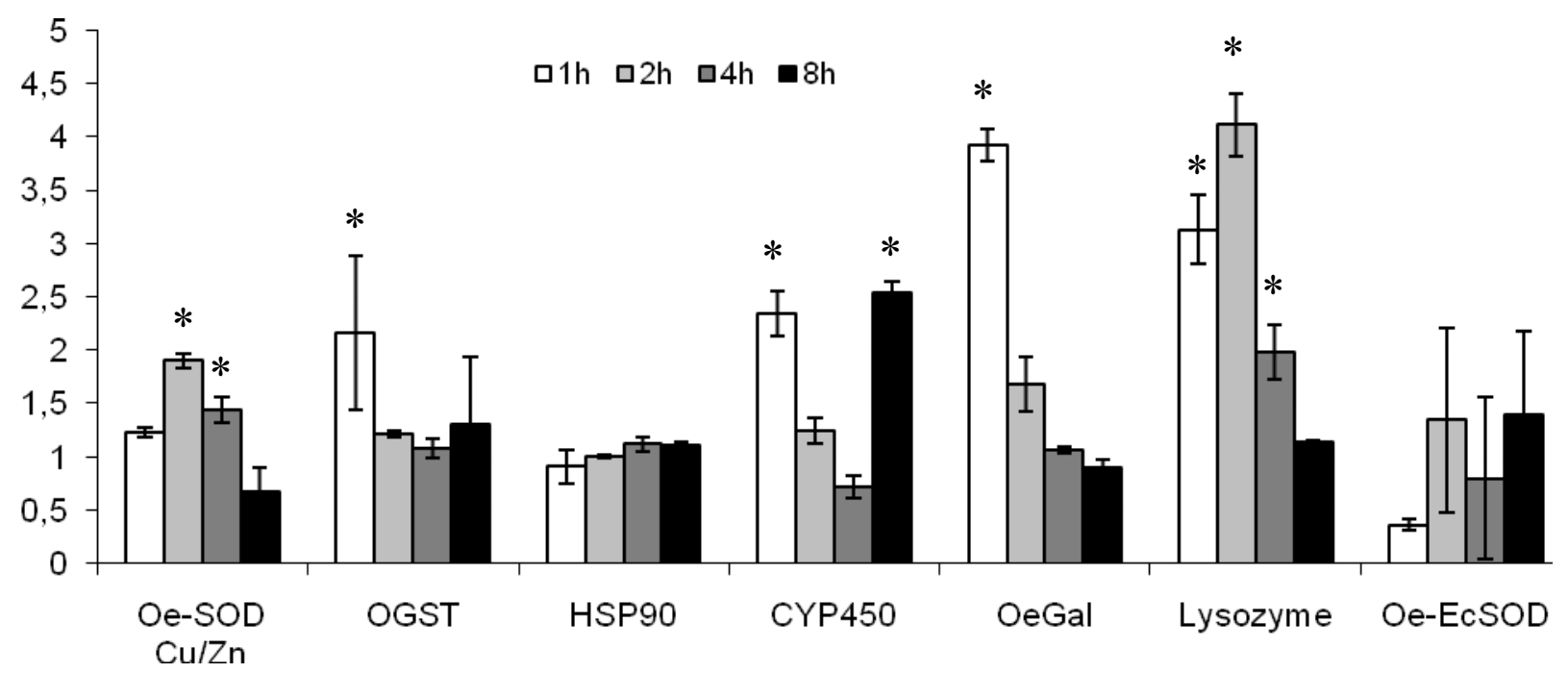

Fig 6 